\author{
Alexander N. Vylegzhanin, Urszula Moskwa
}

\title{
Transboundary pipelines and the Arctic: legal issues
}

According to estimations from the US, about $13 \%$ of the world's undiscovered resources of oil (90 billion barrels), and 30\% of the undiscovered resources of natural gas $(1,669$ trillion cubic feet of natural gas, and 44 billion barrels of natural gas liquids), are situated in a region lying to the north of the Arctic Circle. Over 87\% of the Arctic's oil and natural gas resources (approximately the equivalent of 360 billion barrels of oil) are located in seven Arctic basin provinces: the Amerasia Basin, Arctic Alaska Basin, East Barents Basin, East Greenland Basin, West Greenland East Canada Basin, East Greenland Rift Basin, West Siberian Basin and Yenisey-Khatang Basin. ${ }^{1}$ Some of the Arctic States have only recently attempted to formulate an arctic policy on these resources, due to the environmental risks, technical difficulties and financial costs entailed in developing the Arctic oil and natural gas deposits.

Despite the development of international energy transportation by sea vessels, including the maritime transport of liquefied natural gas, transboundary or cross-border pipelines are considered the most reliable way to transport large volumes of gas internationally, although large investments and adequate international agreements are much needed. ${ }^{2}$ Therefore, the role of cross-border pipelines in contemporary international relations is increasing ${ }^{3}$ and they are considered in this paper as the "future" for oil and gas transportation from the Arctic.

1 US Geological Survey, Circum-Arctic Resource Appraisal: Estimates of Undiscovered Oil and Gas North of the Arctic Circle, fact sheet, 2008, http://pubs.usgs.gov/fs/2008/3049/fs2008-3049.pdf [access: 30.06.2016]; United States Energy Information Administration, Arctic Oil and Natural Gas Resources, December 2012, www.eia.doe.gov [access: 30.06.2016].

2 Pipelines in the United States and Europe and their Legal and Regulatory Aspects, OECD Study, Paris 1969, p. 3.

3 L. Simonet, Pipelines in Geopolitics and in International Relations, "Oil, Gas and Energy Law Intelligence (OGEL)” 2006, no. 4, http://www.gasandoil.com/ogel [access: 30.06.2016]. 


\section{General legal description of cross-border pipelines}

Exploring the international legal regime of pipelines, J. Soubeyrand, professor of Bordeaux University, draws attention to the fact that if the pipeline is laid exclusively within the territory of one state, it is simply an object of national legal regulation. ${ }^{4}$ Whereas pipelines laid in the territory of two or more states, as well as on the seabed, are the object of international law. ${ }^{5}$

It has to be emphasized that, from a legal point of view, the term "pipeline" should not be understood as only the pipe laid on the ground used for oil and gas transportation. ${ }^{6}$ As defined, for example, in the Irish Gas Act of 1976, the term "pipeline" also "includes any apparatus, equipment or other thing which is ancillary to such a pipeline." Cross-border pipelines have their beginnings on the territory of one state, pass through this territory (land or sea - the bed of the internal waters and of territorial sea) and/ or through the continental shelf of another state, as well as, in some cases, through the bed of the high seas. Management of transboundary pipelines - at the stage of their construction and their operational stage - is based on the applicable rules of both international and national law.

Taking into account the actual parameters (including technical ones) of pipelines which cross borders, there are two basic models for the management of such pipelines: a) the "legally unified pipeline" model - when relevant States define a single, coherent legal regime of the pipeline along its entire route; b) the "legally connected pipeline" model (also called the "interconnector pipeline" model) - when the national legislation of each of the States determines the legal regime of "its" section of the pipeline (including protection of the environment, labor relations, taxation, etc.). ${ }^{8}$ The names of pipelines may vary. "Inter-connecting pipeline," under the Framework Agreement between the Government of the United Kingdom of Great Britain and Northern Ire-

4 J. Soubeyrol, La condition juridique des pipe-lines en droit international, "Annuaire Français de Droit International" 1958, vol. 4, pp. 157-161.

5 Международно-правовые основы недропользования [International legal basics of using subsoil], ред. А.Н. Вылегжанин, Москва 2007, pp. 208-2011; А.В. Николаев, Правовой режим подводных трубопроводов (некоторые аспекты международного и российского правa) [The legal regime of submarine pipelines (some aspects of international and Russian law)], “Московский журнал международного права. Специальный выпуск” Май 2006, p. 125.

6 As noted in the multi-volume commentary on the UN Convention on the Law of the Sea 1982, the term "pipelines" refers primarily to those carrying hydrocarbons (both oil and gas), but is not limited to those uses - United Nations Convention on the Law of the Sea 1982, A Commentary, ed. M.H. Nordquist, vol. III, Dordrecht 1995, p. 82.

7 Irish Gas Act, 1976, http://www.irishstatutebook.ie; Международно-правовые..., ор. сіt., p. 211.

8 Ibidem. 
land and the Government of Norway relating to the laying, operation and jurisdiction of inter-connecting submarine pipelines, 1998, serves as a good example of the first model. According to this intergovernmental agreement, an "inter-connecting pipeline" is a "submarine pipeline on the continental shelf, crossing the dividing line between the parts of the continental shelf which appertains to the United Kingdom and that part which appertains to the Kingdom of Norway and linking infrastructure on one side under the jurisdiction of one of the Governments to infrastructure on the other side under the jurisdiction of the other Government" (Article 3). ${ }^{9}$ The pipeline's route "shall be subject to the consent of both Governments" (Article 4). The governments of both parties ensure the appointment of a single "operator for the laying and operation of the pipeline," what is more, any change of the operator "shall be subject to the approval of the two Governments" (Article 5).

Agreement between the Government of the Russian Federation and the Government of the People's Republic of China on cooperation in natural gas supplies from Russia to China via the 'eastern route,' 2014, serves as an example of the other model for the management of transboundary pipelines. Under the Agreement, gas from Russia is transported to China by different parts of a gas pipeline under the sovereignty of the relevant State-Party to the Agreement. The Agreement establishes a regime of "crossborder section of the pipeline," which "starts from the gas distribution station located within the territory of the Russian Federation, and ends with the Haihe distribution station located within the territory of the People's Republic of China." This cross-border section of the pipeline has a peculiar legal regime: the Agreement provides for a special regime for the underwater section (across the Amur River). "Designing and construction of the gas pipeline within the territory of the Russian Federation up till the underwater section is carried out by an authorized organization of the Russian side" and within the Chinese territory (also - up till the underwater section) - by an authorized organization of the Chinese party. "Designing and construction of a gas pipeline across the Amur River" (that is, within the "underwater section") is carried out, however, by "co-authorized organizations" of the two Parties (Article 4). As to the authorized organizations, the agreement identifies them in concreto: from the Russian side - Gazprom; from the Chinese side - China National Petroleum Corporation (Article 3).

\section{Arctic pipelines: basic relevant facts}

The term "Arctic pipelines" can be defined as relating to pipelines laid to the north of the Arctic Circle ( $\left.66^{\circ} 33^{\prime} N\right)$. Transportation of Arctic gas or oil resources will most prob-

9 Ibidem, pp. 436-445. 
ably be done by using such pipelines (including the cross-border ones). ${ }^{10}$ Transboundary pipelines in the Arctic, as well as in other areas of the world, do not have a single international legal regime. The legal regime of each pipeline can be described as monotypic.

The Canadian American Gas Oil Pipeline (so-called Canol) was an oil pipeline constructed during the Second World War. It was the first of the cross-border pipelines constructed in the Arctic. Oil was transported from Norman-Wells (in the Northwest Territories of Canada) to Alaska. The construction began in 1942 and was completed in April 1944. The main pipeline was in use for less than fourteen months. ${ }^{11}$

The international contract on the construction of "the first underground pipeline" in the same area, was signed by the United States and Canada in June 1953 (Contract no. 20 Haines-Fairbanks pipeline). ${ }^{12}$ The international agreement authorized operation of the Haines-Fairbanks Pipeline for 20 years. The government of Canada arranged "for the remission of duties and Federal taxes, on construction equipment, materials and supplies imported into or purchased in Canada, when consigned to the project and used in its construction. ${ }^{13}$ Canada required that certain conditions were met in constructing and operating the pipeline. The Canadian government was primarily interested in protecting its lands from environmental degradation and ensuring that Canadian labor and supplies were used in the construction, operation and maintenance of the pipeline in its country. ${ }^{14}$ The Haines-Fairbanks route traversed two countries - from port Haines (in the south-east of the Alaska state) to the terminal in Fort Wainwright in Fairbanks. The pipeline operated from 1956 to 1973, serving as a military facility. Its construction and service experience became useful during the construction of Trans-Alaska oil pipeline. ${ }^{15}$

During the 1960s, the first pipelines to the north of the Arctic Circle were laid in the USSR. The constructions of the Igrim - Serov gas pipeline and the Shaim - Tyumen oil pipeline were completed in Western Siberia in 1965. At this time, the Igrim - Serov pipeline, through which the first Tyumen gas reached the Northern Ural, was unique and very complex. The economic and technological significance of the experimental Messoyakha - Norilsk gas pipeline is also to be noted. In February 1966, the Messoyakha gas field was explored by geologists; in March 1968, the Minister of the Gas Industry

10 И.В. Буник, Международно-правовые особенности эксплуатащии трубопроводов в Арктике [International legal features of pipeline operation in the Arctic], "Московский журнал международного права. Специальный выпуск» Май 2006, р. 177.

11 P.S. Barry, The Canol Project, "Arctic"1992, vol. 45, no. 4, pp. 401-403.

12 For more details cf. K. Hollinger, The Haines-Fairbanks Pipeline, ed. G.R. Lesondak, Fort Collins 2003, p. 8.

13 Note no. 227, Embassy of the United States of America, Ottawa, April 19, 1962 to Embassy of The Honorable, The Secretary of State for External Affairs, Ottawa.

14 K. Hollinger, op. cit., pp. 8-9.

15 Л. Павлов, Полезные уроки [Useful lessons], “Трубопроводный транспорт нефти” 2011, no. 10 , pp. $62-63$. 
of the USSR signed an order for the construction of a new pipeline (and for the creation of the Zapolyaryegaz office); and in December 1969 a new gas route was put into service. ${ }^{16}$

The main gas and oil pipelines from central and northern districts of the Tyumen region, as well as from the district of Pechora, to the industrial centers in the European part of the country, as well as to the countries of Eastern and Western Europe, were constructed in the 1970s. These were pipelines of large diameter, with a length of several thousand kilometers.

Currently, in Russia a number of pipelines have their beginning to the north of the Arctic Circle. For example, the SRTO - Torzhok gas pipeline is primarily targeted at supplying more gas to consumers in Northwestern Russia and securing gas exports via the Yamal - Europe gas pipeline. ${ }^{17}$ In 2013, the Vankor - Khalmerpayutinskoye field pipeline started transporting gas to the Unified Gas Supply System. In 2014, the construction of an oil pipeline from the Messoyakha fields (the northernmost of the known Russian onshore oil fields) started. The most northern pipeline in the Russian Federation is the Zapolyarie - NPS purpe oil pipeline. It should be noted that one of the longest gas pipelines in the world $(4451 \mathrm{~km})$ - Urengoy - Pomary - Uzhgorod (the socalled "Brotherhood" Pipeline), also has its beginning north of the Arctic Circle. It was constructed in 1984 and it transported natural gas from the USSR (from Russia, via the Ukrainian Soviet Republic) to Eastern and Western European countries.

The Trans-Alaska oil pipeline is the largest pipeline in the USA, crossing the Arctic Circle. The pipeline was built between 1974 and 1977, after the 1973 oil crisis. In 1973, after many years of disputes and discussions, the United States Congress approved the construction of this pipeline. ${ }^{18}$ The Trans-Alaska Pipeline Authorization Act of 1973 removed all legal barriers from the construction of the pipeline, provided financial incentives, and granted a right-of-way for its construction. ${ }^{19}$ It was suggested in the Act that "a supplemental pipeline to connect the North Slope with a trans-Canada pipeline" could be constructed. In spite of this, according to the Act, the pipeline cannot be considered as a transboundary one, since it "does not traverse a foreign country" (Sec. 202d). The alternative route across Canada was much deliberated, but the concept was eventu-

16 С.А. Стрючков, Новая эпоха в энергетике [New Epoch in Energy Development], “Заполярный Вестник” 2013, http://norilsk-zv.ru/articles/novaya_epoha_v_energetike.html [access: 30.06. 2016].

17 Gazprom's official website: http://www.gazprom.ru/about/production/projects/pipelines/srtotorzhok/ [access: 30.06.2016].

18 The Trans-Alaska Pipeline Authorization Act of 1973, title 43, section $1651^{\text {st }}$ of the United States Code, 43 U.S.C. of $\S 1651$.

19 For more details cf. R.A. Fineberg, Lessons from the Trans-Alaska Pipeline System, TAPS Lessons (PERC), Pacific Environment, 2002, http://pacificenvironment.org/downloads/Oilgas_ 2002_\%20TAPS_lessons_Fineberg.pdf [access: 30.06.2016]. 
ally rejected because of "the possibility of indefinite delays or even the project's ultimate impossibility." Sec. 301 of the Act asserts, however, that:

The President of the United States is authorized to enter into negotiations with the Government of Canada to determine: (a) the willingness of the Government of Canada to permit the construction of pipelines, (b) the need for intergovernmental understandings, agreements, or treaties, (c) the terms and conditions under which pipelines or other transportation systems could be constructed...

In general, the Act provides for the use of state-of-the-art technology, to protect and preserve the environment while still paying heed to economic practicalities during the construction, operation, and maintenance of the pipeline.

The Northstar oil pipeline (in use since 2002) is considered the first successful subsea Pipeline in the Arctic.

In 2015, the construction of the Polarled gas pipeline began and, for the first time in the history of Norway, a Norwegian pipeline is to cross the Arctic Circle. The pipeline will link the Aasta-Hansteen field in the Norwegian Sea with the west coast of Norway. This will open a new gas route from the Norwegian Sea to Europe.

Pipelines in the Arctic region can be laid on different seabed areas of the Arctic Ocean: a) being "under the sovereignty" (the seabed of "internal waters" and "territorial sea") of a particular Arctic State; b) or under the "jurisdiction" ("continental shelf") of such a State. By "such a State" here, we mean one of the five Arctic Coastal States, the shores of which are washed by the Arctic Seas and which have legal claims to areas of the continental shelf in the Arctic Ocean: Denmark, Norway, Russia, the USA, and Canada. Regardless of when exactly the delimitation of the continental shelf areas in the high northern latitudes between the Arctic Coastal States will be completed, ${ }^{20}$ management of pipelines in these areas requires the application of the national laws of each of the Arctic Coastal States involved, and of the relevant rules of international law - first of all, specific agreements on the management of transboundary fields and pipelines.

In 2010, the Russian Federation and the Kingdom of Norway signed the Treaty concerning Maritime Delimitation and Cooperation in the Barents Sea and the Arctic Ocean. The Parties have reached a solution which is based on modern principles of international law relating to both marine living resources and oil and gas deposits - the delimitation of marine spaces and management of shared natural resources. The Agree-

20 А.Н. Вылегжанин, С.А. Гуреев, Г.Г. Иванов, Международное морское право [International Law of the Sea], Москва 2003, pp. 224-226; Арктический регион: Проблемы международного сотрудничества. Хрестоматия в 3 томах [Arctic Region: Problems of International Cooperation. Chrestomathy in 3 volumes], т. 3, Применимые правовые источники, ред. И.С. Иванова, Москва 2013, р. 32. 
ment defines a single maritime boundary that divides the States-Parties' continental shelves and specifies exclusive economic zones in the Barents Sea and the Arctic Ocean; according to the Agreement, the States-Parties have taken on the obligation to continue their cooperation in the sphere of fisheries. The Agreement contains special provisions on the coordinated exploitation of transboundary hydrocarbon resources, which defines its own model for the management of transboundary oil and gas reserves in the Arctic, as provided in Annex II (titled "Transboundary Hydrocarbon Deposits"). ${ }^{21}$

It should be recalled that in 2009, the Arctic Council adopted the Arctic Offshore Oil and Gas Guidelines. Ministers of the Arctic States initially adopted this document during the Fourth Ministerial Conference on the Protection of the Arctic Environment in June 1997. The document focuses mainly on the problems of environmental protection in the Arctic region, as well as on the principles of the marine oil and gas activities of the Arctic States, inter alia, during the stage of development, exploration, production, and withdrawal from service. In accordance with Clause 1.3, the Arctic maritime oil and gas activities must be based on the following principles: 1 . The Principle of the Precautionary Approach reflected in Principle 15 of the Rio Declaration on Environment and Development of 1992; 2. The Polluter Pays Principle reflected in Principle 6 of the Rio Declaration; 3. Continuous Improvement - all parties should continually strive to improve health, environment and safety by identifying the processes, activities and products that need improvement, and implement necessary improvement measures; 4. Sustainable Development.

In April 2015, the government of the Kingdom of Denmark, the Government of Iceland, the Government of Canada, the Government of the Kingdom of Norway, the Government of the Russian Federation, the Government of the United States, the Government of the Kingdom of Sweden, and the Government of Finland adopted the Framework Plan for Cooperation on Prevention of Oil Pollution from Petroleum and Maritime Activities in the Marine Areas of the Arctic. The plan, consisting of four Chapters, is aimed at strengthening cooperation between the participants in the prevention of oil pollution at sea and the protection of the Arctic environment in general.

\section{Applicable International law}

\section{"Freedom of transit" in international law}

Article 23 of the Covenant of the League of Nations declared the general purpose "to secure and maintain freedom of communications and of transit." Subsequent multilateral

21 А.Н. Вылегжанин, Правовая модель управления трансграничными минеральными ресурсами в западной части Арктической зоны Российской Федерации [Legal Model of Management of Transboundary Marine Mineral Resources in Western Part of the Arctic zone of the Russian Federation], “Арктика: экология и экономика” 2011, по. 2, p. 4. 
international treaties did not provide for any "hard" obligations of a State to grant the right of transit through its territory to a foreign state; most of such agreements provided for rather the general possibility of such a transit (sometimes in vague terms). Contractual provisions which definitely encourage such a transit are contained in the Barcelona Convention of 1921 and the Statute on Freedom of Transit, as well as in the General Agreement on Tariffs and Trade (Annex 1A to the Agreement Establishing the World Trade Organization, 1994). These multilateral contractual regulations do not imply the recognition by the States-Parties of an unconditional right of transit through the territory of a foreign State. So it was generally understood that laying a pipeline requires special (most often - bilateral) agreement between the States concerned. Nevertheless, the provisions of the multilateral international treaties cited above are in practice taken into account by the States concerned while specifying the legal regime of a particular cross-border pipeline, including its components, such as safety, transit procedures, commercial rates, taxes, protection of the environment, and others. In this respect, Article V of the GATT 1994, which confirms the freedom of transit, plays an important role. Although Russia is not party to the Energy Charter Treaty, it is necessary to mention that Article 7 ("Transit") provides, inter alia that: "each Contracting Party shall take necessary measures to facilitate the transit of energy materials and products consistent with the principle of freedom of transit". And further:

\begin{abstract}
[...] contracting Parties shall encourage relevant entities to co-operate in: (a) modernizing energy transport facilities necessary to the transit of energy materials and products; (b) the development and operation of energy transport facilities serving the areas of more than one contracting party; (c) measures to mitigate the effects of interruptions in the supply of energy materials and products; (d) facilitating the interconnection of energy transport facilities.
\end{abstract}

\title{
Provisions of international law of the sea
}

The main international treaty which regulates, on a global level, the relations between States concerning laying pipelines on the seabed, as well as the ones concerning the exploitation of those pipelines, is currently the United Nations Convention on the Law of the Sea 1982 (hereinafter - the 1982 Convention).

\section{Pipelines on the seabed of internal waters and territorial sea}

According to the 1982 Convention, the sovereignty of a coastal State extends to its internal waters and territorial sea, including their bed (Article 2). By virtue of this sovereignty, if a pipeline crosses areas of the sea-bed of internal waters, or the territorial seas, of both State A and State B, each of them has the right to determine the procedure and 
conditions for laying the pipeline section "within its territory." However, in practice, to control the whole cross-border pipeline of this kind, the relevant neighboring States reach an agreement. When it comes to laying such a pipeline by the entity of a third State, or by a consortium of individuals from the third States (i.e., by those States that are not sovereigns in respect of these seabed territories), the relevant agreement on the cross-border pipeline involves all those concerned States. However, even in this case, the will of the territorial sovereigns - States A and B - is crucial. The coastal State may adopt, in conformity with the provisions of the Convention and other rules of international law, laws and regulations relating to innocent passage through the territorial sea, including inter alia in respect of "the protection of cables and pipelines" (Article $21 \S 1$ ).

\section{Pipelines on the continental shelf}

The seabed and subsoil of the submarine areas that extend beyond State's territorial sea, constituting the natural prolongation of its land territory, is "the continental shelf" of a coastal State. In accordance with general International Law, the sovereign rights "of the coastal State in respect of the area of continental shelf that constitutes a natural prolongation of its land territory into and under the sea exist ipso facto and ab initio." 22 The sovereign rights of the coastal State over its continental shelf, for the purpose of exploring the seabed and exploiting its natural resources (and also protecting marine environment), coexist, however, with the right of other States to lay cables and pipelines on the continental shelf (Article 79 of the 1982 Convention). Taking into consideration the above-mentioned, a correct interpretation of this article is crucial. It provides that: 1) all States "are entitled to lay submarine cables and pipelines on the continental shelf, in accordance with the provisions of this article" - \$1.2). "When laying submarine cables or pipelines, States shall have due regard to cables or pipelines already in position. In particular, possibilities of repairing existing cables or pipelines shall not be prejudiced" - 5 . Therefore, the above-mentioned reflects (in this special sphere) a general principle of law - quieta non movere. Under Article 79 2, the coastal State may not impede the right of another State to lay or maintain cables or pipelines on the continental shelf. The right of the coastal State "to take reasonable measures for the exploration of the continental shelf, the exploitation of its natural resources and the prevention, reduction and control of pollution from pipelines," however, is implied as "a priority right." Article 4 of the Convention on the Continental Shelf, 1958, reiterates that provision, adding the obligation to prevent pollution from pipelines. Neither this Article, nor Article 79 of the 1982 Convention give an expressis verbis answer to the question of whether the prior-

22 It is the most fundamental of all the rules relating to the continental shelf - ICJ Reports, 1969, p. 22. For details cf. for example: А.Н. Вылегжанин, Решения Международного Суда ООН по спорам о разграничении морских пространств [Judgments of the International Court of Justice relating to marine delimitation disputes], Москва 2004, pp. 49-55. 
ity right of a coastal State designated above is still applicable in a situation when such a State does not take "reasonable measures" to explore and exploit the natural resources of its continental shelf, at the stage of laying a pipeline; and then, when the cross-border pipeline has already been laid, such a coastal State decides to take such measures. While answering this question, it should be considered, firstly, that according to the UN International Law Commission's commentary on the draft-articles on the law of the sea (1956), the rules relating to the protection of underwater telegraph and telephone cables can be extended to underwater pipelines. ${ }^{23}$ Secondly, in this case, the consented will of the coastal State and of the other relevant States-Parties to the agreement on a crossborder pipeline will be regarded as lex specialis. In the context of such a special international agreement, the demand of the coastal State to dismantle a cross-border pipeline, since the State has unexpectedly decided to explore the resources of its continental shelf, cannot be considered as legitimate (based on the lex generalis - provisions on its sovereign rights to the resources of the continental shelf). The International Court of Justice, or another relevant tribunal, will most likely recognize this requirement as illegitimate, referring to the basic principle of international law - pacta sunt servanda, and to its cumulative effect with general principles of law: lex specialis derogat generali; primus in tempore potior est in jure. The situation seems more complicated, however, if there is no agreement on cross-border pipeline between the coastal State and other relevant States, or if such an agreement was concluded in general terms, without any details relating to the issue. Even in this case, the consent of a coastal State is usually presumed; in any case the consent of the relevant coastal State, in accordance with Article $79 \S 3$ of the 1982 Convention, is a key factor. Formally, the consent of the coastal state is required only for "the delineation of the course for the laying of such pipelines on the continental shelf" (Article $79 \S 3$ ). This requirement is consistent with $\S 2$ of the same article, cited above, which allows the coastal State to prevent crossing by a pipeline through reserves of oil and gas, or habitats of the sedentary species, thereby preventing competition between different actors of economic activities in the shelf-area affected, at the stage when a pipeline has not yet been laid yet. In the context of $\S 2$ of the same article, this requirement allows the coastal State to prevent the deterioration of the environment caused by the laying of a pipeline in a particular area of the shelf (for example, when information is available about the long-term seismic activity in such an area). The same requirement allows the coastal State to create the infrastructure for the best possible reduction of eventual pollution from a pipeline (taking into account, for example, the location of specialized service to combat oil spills and gas leaks). The coastal State also has jurisdiction over the pipelines, which are laid or used "in connection with the exploration of its

23 Международно-правовые..., ор. сіt., pp. 212-213. 
continental shelf or exploitation of its resources or the operations of artificial islands, installations and structures under its jurisdiction" (Article $79 \S 4$ ). This provision serves as reaffirmation of the sovereign rights which a coastal State exercises over its continental shelf for the purpose of exploring it and exploiting its natural resources; it does not raise additional questions, but requires careful interpretation. Under the 1982 Convention, every activity concerning natural resources on the continental shelf of the coastal State (including the activity of laying a pipeline to transport hydrocarbons from a field which is located within the subsoil of the shelf) is permissible only with "the express consent of such a State" (Article $77 \S 1$ ).

In accordance with Article 78, "the rights of the coastal State over the continental shelf do not affect the legal status of the superjacent waters" (Article $78 \S 1$ ). The provision is basically a reproduction of Article 3 of the Convention on the Continental Shelf 1958. The term "superjacent waters" is defined in the United Nations document as "the waters lying immediately above the seabed or deep ocean floor up to the surface." 24 The same concept appears in the Convention named "water column," although in a different context (Article 287).

Under Article $78 \S 2$, the exercise of the rights of a coastal State over the continental shelf "must not infringe or result in any unjustifiable interference with navigation and other rights and freedoms of other States as provided for in this Convention." The categorical nature of this conventional obligation of the coastal State, expressed by the word "must not," has to be emphasized. That is, in this context, activities relating "to exploration of natural resources of the coastal State on its shelf are subject to the principle of freedom of navigation in the surface waters, " regardless of whether they are the waters of the high seas or of the exclusive economic zone. The obligation of a coastal State not to infringe the conventional rights of other States, were stated in the same categorical manner. Those rights include "the right of other States to lay pipelines on the continental shelf" and a coastal State is not permitted to create unjustified interference with the realization of this right.

It is indicated in the literature of the subject that the pipelines connecting "offshore fields to the coast," ${ }^{25}$ are as a rule subject to international agreements, for example, to interna-

24 UN Office for Ocean Affairs and the Law of the Sea, Baselines: An Examination of the Relevant Provisions of the UN Convention on the Law of the Sea, Appendix I (Glossary of Technical Terms), UN Publication Sales no. E88. vol. 5, 1989, p. 47.

25 И.В. Гудков, Трансграничные трубопроводы: некоторые аспекты правового регулирования [Transboundary pipelines, some aspects of legal regulation], "Нефть, газ и право. Журнал правовой коммерческой информации в области недропользования и энергетики” 2008, no. 6 , p. 30. 
tional agreements on concrete pipelines laid in the North Sea. ${ }^{26}$ There are also agreements ${ }^{27}$ (bilateral and multilateral), which establish certain general principles and obligations with respect to cross-border pipelines. ${ }^{28}$ The analysis of those international agreements leads to the conclusion that each individual cross-border pipeline laid on the continental shelf has a unique legal regime, which depends on a number of specific circumstances. ${ }^{29}$

\section{Pipelines on the bed of the high seas (outside the continental shelf)}

According to $\S 1$ of Article 87 of the 1982 Convention, the high seas "are open to all States," and the freedom of the high seas comprises, inter alia, the "freedom to lay submarine cables and pipelines." The Convention on the High Seas, 1958, provides that the freedom of the high seas comprises, inter alia, the "freedom to lay submarine cables and pipelines" (Article 2 §). The 1982 Convention, however, reflects a legal innovation: the freedom to lay pipelines on the bed of the high seas is exercised "subject to Part VI" of this Convention (Article $87 \S 1$ ). Reference to Part VI - to provisions on the continental shelf - in the provisions on the high seas (as well as other cross-references in the Convention) reflect "the interrelated nature of the various maritime zones" from the point of view of international law. ${ }^{30}$ Article $87 \S 2$ obliges States to exercise the freedom of the high seas, "with due regard for the interests of other States in their exercise of the freedom of the high seas." This, as noted, is a kind of "test of reasonableness" in the exercise of the freedom of the high seas by all States. ${ }^{31}$ Article 112 confirms that "all States are

26 For example: Agreement between the Government of the United Kingdom of Great Britain and Northern Ireland and the Government of the Kingdom of the Netherlands relating to the Transmission of Natural Gas through a Pipeline between the United Kingdom of Great Britain and Northern Ireland and the Kingdom of the Netherlands signed on 21.03.2005 (BBL pipeline); Convention between the government of Belgium and the government of the United Kingdom of Great-Britain and Northern Ireland on the transport of gas by pipeline between Belgium and the United Kingdom signed on 10.12.1997 (Interconnector pipeline); Agreement between the Government of the Federal Republic of Germany and the Kingdom of Norway concerning the transport of gas by pipeline from the Norwegian continental shelf and other areas to the Federal Republic of Germany signed on 20.04.1993.

27 For example: Framework Agreement between the Government of the United Kingdom of Great Britain and Northern Ireland and the Government of the Kingdom of Norway concerning Cross-Boundary Petroleum Co-operation signed on 4.04.2005; United States-Canada Transit Pipeline Agreement signed on 28.01.1977.

28 S. Vinogradov, Challenges of Nord Stream: Streamlining International Legal Frameworks and Regimes for Submarine Pipelines, "German Yearbook of International Law" 2009, vol. 52, pp. 241-292.

29 С. Виноградов, Международно-правовой режим трансграничных трубопроводов [International legal regime of transboundary pipelines], “Московский журнал международного права. Специальный выпуск” Май 2006, p. 144.

30 United Nations Convention on the Law of the Sea 1982, A Commentary, ed. M.H. Nordquist, vol. III, 1995, p. 73.

31 Ibidem, p. 74. 
entitled to lay submarine cables and pipelines on the bed of the high seas beyond the continental shelf submarine cables and pipelines" $(\$ 1)$. Thus, such a description of the legal regime of pipelines laid on the bed of the high seas, in combination with what was considered above (that is, about the articles on the status of the seabed of the internal waters and territorial sea, as well as Article 79 - on pipelines laid on the continental shelf) completes a comprehensive legal regime for laying and operating pipelines in any part of the seabed.

The 1982 Convention provides "only the right of the 'States' to lay pipelines" on the seabed and to keep pipelines in good condition. In practice, however, the specific "legal entities" ("companies," including "transnational" ones, "consortia," including "international" ones), with the participation of States' capital or without it, exercise that right. It can be noted here that, according to many international treaties, an analogy with the two-level management of the transboundary hydrocarbon deposits can be drawn: the higher, inter-State level. First, State A, which exercises sovereign rights on part of the area of the continental shelf, plays a key role in giving consent as to the delineation of the course for the laying within this area of a cross-border pipeline; and State B, which has the right to another part of the continental shelf, plays a similar role within this part of the shelf; and States A and B might reach an agreement between themselves and might not; what is an obligation is that both these States - A and B - agree with interested States upon the delineation of the course for the laying of transboundary pipelines. A subordinate private law mechanism also exists here: where the companies of State A and/or the companies of State B (which are usually - but not always - involved in the transboundary pipelines project) reach international contracts with other investors of the pipelines project. Key contours of that second - private law level mechanism - are prescribed by the first level - of inter-State relations. ${ }^{32}$

According to the 1982 Convention, the States-Parties adopt such laws and regulations that are necessary to provide that the breaking or injury of a submarine cables or pipelines laid beneath the high seas is considered a punishable offence (Article 113). In addition, Article 114 obliges States-Parties to adopt laws and regulations, "necessary to provide that, if persons subject to its jurisdiction who are the owners of a submarine cable or pipeline beneath the high seas, in laying or repairing that cable or pipeline, cause a break in or injury to another cable or pipeline, they shall bear the cost of the repairs" of the damaged object. The liability for breaking or damaging the "other" pipeline (or cable) is only limited to the cost of repair here. There is no obligation to replace the damaged pipeline, or to compensate the owner for all the financial losses due to such damage. ${ }^{33}$ While interpreting Article 114, the Commentary to the 1982 Convention, quoted above, does not take into consideration this practical question: what are the legal

32 А.Н. Вылегжанин, ор. cit., p. 4 et seq.

33 United Nations Convention on the Law of the Sea 1982, op. cit., p. 273. 
consequences if the other (foreign) pipeline or cable is damaged not by people, to whom the first pipeline (or cable) "belongs;" but by other persons (for example, a company hired by the owner of the first pipeline for its repairs)? It seems that in this case the laws and regulations of the States-Parties, which are mentioned in Article 114, should include designated responsibilities, i.e. the duties of those at fault (although the first pipeline did not "belong" to them) to bear the costs of repairing of the other (damaged) pipeline.

Management of cross-border pipelines requires taking into consideration the "competition" between different uses of the seabed and marine waters above it, including harvesting of living marine resources. According to Article 115 of the 1982 Convention, each State-Party "shall adopt the laws and regulations necessary to ensure that the owners of ships who can prove that they have sacrificed an anchor, a net or any other fishing gear, in order to avoid injuring a submarine cable or pipeline shall be indemnified by the owner of the cable or pipeline." The rule quoted above is not novel in International Law. Such a rule is reflected in Article 29 of the Convention on the High Seas, 1958, with reference to the Convention for the Protection of Submarine Telegraph Cables, 1884. In this context, the Commentary on the 1982 Convention suggests a sort of practical model of such indemnifying, in cases provided in Article 115 - following the Commentary of the International Law Commission (1956) and the text of the Convention for the Protection of Submarine Cables (1884) - immediately after the accident (a loss of an anchor, a net or any other fishing gear "in avoiding injury to a submarine cable or pipeline"), in proof thereof, the captain of the vessel must prepare "a statement supported by the testimony of the men belonging to the crew;" within "twenty-four hours after arriving at the first port of temporary entry," the captain must make this declaration "to the competent authorities; the latter shall give notice thereof to the consular authorities of the nation" to which the owner of the cable or the pipeline belongs. ${ }^{34}$ It might be suggested that if such declarations of captains become numerous, some practical guidelines might be construed by the UN Secretariat as an interpretation of Article 115. An alternative approach - that each State might adopt its own guidelines and include them in its laws and regulations under Article 115 - might lead to different practices of the States.

\section{Applicable rules of international environmental law}

Environmental provisions of Part XII of the Convention undoubtedly apply to regulate relations between the States-Parties concerning laying and operating submarine pipelines. Among other conventional sources of international environmental law, one should list: the Convention on Environmental Impact Assessment in a Transboundary Context, 1991; the Convention on Biological Diversity, 1992; the International Convention for the Prevention of Pollution from Ships, 1973 (with Protocol of 1978); the Convention

34 Ibidem, pp. 277-278. 
Concerning the Protection of the World Cultural and Natural Heritage, 1972, etc. The norms of such international environmental agreements are, in general, considered as well-known, ${ }^{35}$ and will not be discussed in this paper.

\section{Conclusion}

In the universal sources of modern international law, the regime of cross-border pipelines is set out only in general terms. It is true even regarding the 1982 UN Convention on the Law of the Sea, which provides the most developed regulations relating to laying such pipelines. National legal rules applicable to laying pipelines, however, in practice provide for additional requirements which go beyond conventional rules. Relevant national laws are often based on international environmental law, including multilateral environmental treaties. Existing regional treaties providing regulations on cross-border pipelines are most often also of a framework nature.

It has to be emphasized, however, that international practice is developing towards the creation and application of a specific legal regime for each individual cross-border pipeline (by those States whose territories the pipeline crosses, most often, on a bilateral basis). Taking into account the large scale of investments needed for the construction of cross-border pipelines - especially in the Arctic - and the slow rate of return on such investments, the relevant environmental risks of economic activity in the Arctic region, detailed bilateral agreements of the interested States seem to be the most appropriate legal basis for the management of laying and exploiting cross-border pipelines in this region. Still the world legal experience is taken into account by the Arctic States, though not automatically, as was demonstrated by the 2010 Norway-Russia Treaty on Delimitation and Cooperation in the Barents Sea and the Arctic Ocean. It is suggested that an additional Annex to this Treaty might be appropriate for establishing an intergovernmental mechanism for managing cross-border pipelines projects, as well as a private-law mechanism of cooperation between the companies-investors of such a project, including the procedure of designating the pipeline's operator and agreement on a preferential regime for such a pipeline project, concerning both the construction and operation of the pipeline.

The successful management of each of the cross-border pipelines in the Arctic will most probably be provided by the interaction at the international public law level (between the States concerned) and the private law level (between the relevant companies-investors). Not only will the legal regime of each arctic pipeline most probably be described as monotypic; the bargaining positions of the Arctic States concerned, as

35 Е.Е. Андреева, А.В. Кукушкина, Международно-правовые основы охраны окружающей среды [International legal framework for the protection of the environment], [in:] Международное право. МГИМО МИД России, ред. А.Н. Вылегжанина, Москва 2015. 
42 | Adam Mickiewicz University Law Review

well as the negotiation environment, will most probably be unique for each particular pipeline-project.

\section{Literature}

Barry P.S., The Canol Project, "Arctic"1992, vol. 45, no. 4.

Hollinger K., The Haines-Fairbanks Pipeline, ed. G.R. Lesondak, Fort Collins 2003.

Soubeyrol J., La condition juridique des pipe-lines en droit international, "Annuaire Français de Droit Inernational" 1958.

United Nations Convention on the Law of the Sea 1982. A Commentary, ed. M.H. Nordquist, vol. III, 1995.

Vinogradov S., Challenges of Nord Stream: Streamlining International Legal Frameworks and Regimes for Submarine Pipelines, "German Yearbook of International Law” 2009, vol. 52 .

Андреева Е.Е., Кукушкина А.В., Международно-правовые основы охраны окружаюшей среды, Международное право. МГИМО МИД России, ред. А.Н. Вылегжанин, Москва 2015.

Арктический регион: Проблемы международного сотрудничества. Хрестоматия в 3, т. 3, Применимые правовые источники, ред. И.С. Иванов, Москва 2013.

Буник И.В., Международно-правовые особенности эксплуатащии трубопроводов в Арктике, “Московский журнал международного права,” Специальный выпуск, Май 2006.

Виноградов С., Международно-правовой режим трансграничных трубопроводов, “Московский журнал международного права," Специальный выпуск, Май 2006.

Вылегжанин А.Н., Международно-правовые основы недропользования, Москва, 2007.

Вылегжанин А.Н., Правовая модель управления трансграничными минеральными ресурсами в западной части Арктической зоны Российской Федерации, “Арктика: экология и экономика" 2011, nо. 2.

Вылегжанин А.Н., Решения Международного Суда ООНпо спорам оразграничении морских пространств, Москва 2004.

Вылегжанин А.Н., Гуреев С.А., Иванов Г.Г.. Международное морское право, Москва 2003.

Гудков И.В., Трансграничные трубопроводы: некоторые аспекты правового регулирования, “Нефть, газ и право. Журнал правовой коммерческой информации в области недропользования и энергетики” 2008, no. 6. 
Николаев А.В., Правовой режим подводных трубопроводов (некоторые аспекты международного и российского права), “Московский журнал международного права. Специальный выпуск” Май 2006.

Павлов Л., Полезные уроки, “Трубопроводный транспорт нефти” 2011, no. 10.

http://norilsk-zv.ru/articles/novaya_epoha_v_energetike.html [access: 30.06.2016]. http://pacificenvironment.org/downloads/Oilgas_2002_\%20TAPS_lessons_Fineberg. pdf [access: 30.06.2016].

http://www.gazprom.ru/about/production/projects/pipelines/srto-torzhok/ [access:30.06. 2016].

http://www.gasandoil.com/ogel [access: 30.06.2016].

\section{SUMMARY}

\section{Transboundary pipelines and the Arctic: legal issues}

In the universal sources of modern international law, the regime of cross-border pipelines is set out only in general terms. It is true even regarding the 1982 UN Convention on the Law of the Sea, which provides the most developed regulations relating to laying such pipelines. National legal rules applicable to laying pipelines, however, in practice provide for additional requirements which go beyond conventional rules. Relevant national laws are often based on international environmental law, including multilateral environmental treaties. Existing regional treaties providing regulations on cross-border pipelines are most often also of a framework nature.

Keywords: international law, Transboundary pipelines, Arctic

Alexander N. Vylegzhanin, Moscow State Institute of International Relations, International Law School, 76, Prospect Vernadskogo Moscow, Russia, 119454, e-mail: sopspravo@mail.ru.

Urszula Moskwa, Moscow State Institute of International Relations, International Law School, 76, Prospect Vernadskogo Moscow, Russia, 119454, e-mail: moskwaurszula@gmail.com. 